\title{
MIMIKRI DAN STEREOTIPE KOLONIAL TERHADAP BUDAK DALAM NOVEL-NOVEL BALAI PUSTAKA
}

\author{
I Gde Artawan ${ }^{1}$, I Nyoman Yasa ${ }^{2}$ \\ 1,2 Jurusan Pendidikan Bahasa Indonesia \\ Universitas Pendidikan Ganesha \\ Singaraja Indonesia
}

Email: Loekan.djati@yahoo.com

\begin{abstract}
Abstrak
Penelitian ini bertujuan mengungkap 1) mimikri yang dilakukan oleh pribumi dalam upaya untuk mempertahankan eksistensi diri di tengah gempuran kolonial Belanda. 2) Stereotipe kolonial terhadap terhadap pribumi. Subjek penelitian adalah novel-novel Balai Pustaka seperti Siti Nurbaya (Marah Rusli), Salah Asuhan dan Pertemuan Jodoh (Abdoel Moeis). Obeknya asdalah mimikri dan stereotife kolonial terhadap budak. Penelitian kualitatif ini menggunakan metode studi pustaka dalam mengumpulkan data. Analisis data mengunakan metode analisis deskriptif dengan teori postkolonial. Teori postkolonial merupakan sebuah istilah bagi sekumpulan strategi teoretis dan kritis yang digunakan untuk meneliti kebudayaan (kesusastraan, politik, sejarah, dan seterusnya) dari koloni-koloni negara-negara Eropa dan hubungan mereka dengan negara-negara lainnya di dunia.
\end{abstract}

Kata kunci: mimikri, stereotipe kolonial, novel balai pustaka

\begin{abstract}
This research aims to uncover 1) mimicry performed by natives in an attempt to maintain the existence of the self in the middle of the Dutch colonial onslaught. 2) against the colonial stereotype of the natives. Subjects were novels such as Siti Nurbaya Balai Pustaka (Marah Rusli), One Care and Meeting Houses (Abdul Muis). Obeknya asdalah colonial mimicry and stereotife against slaves. This qualitative study using literature methods in collecting the data. Data analysis using descriptive analysis method with postcolonial theory. Postcolonial theory is a term for a set of theoretical and critical strategies used to examine the culture (literature, politics, history, and so on) of the colonies of European countries and their relations with other countries in the world.
\end{abstract}

Key words: mimicry, colonial stereotype, balai pustaka novel 


\section{PENDAHULUAN}

Balai Pustaka (1908-1942) didirikan oleh kolonial Belanda dalam upaya melakukan kontrol sosial dan politik terhadap bacaan-bacaan liar (teks bacaan yang diterbitkan oleh komunitas Tionghoa, Arab, dan Pribumi) di Indonesia. Kontrol sosial dan politik tersebut dilakukan dalam upaya mengeksistensikan dirinya sebagai satusatunya penjajah yang menaklukkan pribumi seuntuhnya. Oleh karena itu, semua bacaan yang diterbitkan ada dalam pengawasan dan sensor kekuasaannya. Herawati (2010: 200) menyatakan bahwa Belanda memanfaatkan karya sastra sebagai media hegemoni dan dominasi terhadap rakyat pribumi. Kolonial Belanda merekrut pegawai-pegawai kontrak untuk mengurus Balai Pustaka. Abdoel Moeis adalah salah satu contohnya. Ia diupah tinggi sebagai tenaga kerja di Balai Pustaka. Begitu pun, Sutan Takdir Alisyahbana (Faruk, 2007: 50). Kontrol sosial dan politik yang dilakukan, bukan saja kepada pribumi sebagai tenaga kerja, tetapi juga pengarang (sastrawan) sekaligus karya sastra yang diterbitkan ketika itu.

Novel Salah Asuhan, Siti Nurbaya, dan Belenggu adalah karya sastra-karya sastra yang sudah mengalami sensor dari tangan kolonial sebelum akhirnya teks-teks (novelnovel) itu dibaca masyarakat pribumi. Novel-novel itu harus sesuai dengan standar bacaan yang sudah ditetapkan oleh Balai Pustaka berdasarkan keputusan D.A. Ringkes; salah satunya adalah karya sastra yang diterbitkan tidak bertentangan dengan garis politik pemerintah Belanda (Sarwadi, 2004: 28). Dalam sensor yang dilakukan, kolonial menciptakan sebuah pencitraan diri, orientalisme, dan tetap menempatkan pribumi sebagai budak. Budak pekerja dan budak peniru budaya-budaya Barat. Walaupun demikian, novel-novel Balai Pustaka juga menunjukkan perlawanann secara tersembunyi dari para pengarang. Darma (2010, 172) menyatakan bahwa dalam karya sastra, dikotomi antara penindas dan tertindas tidak selamanya eksplisit. Novel Azab dan Sengsara misalnya. Azab dann Sengsara menunjukkan perlawanan dari pribumi (Mahayana, 1994:18-19).

Pencitraan diri, orientalisme, perbudakan, dan perlawanan masyarakat pribumi dalam karya sastra terbitan Balai Pustaka tidak lepas dari akumulasi kegelisahan, penderitaan yang dialami masyarakat pribumi semenjak kedatangan Belanda ke Indonesia. Peristiwa-peristiwa sosial budaya ataupun peristiwa sejarah yang terjadi dan berkembang dalam masyarakat direkam berdasarkan sensitivitas sastrawan (Yasa, 2010: 51) dan kemudian ditransformasi ke dalam karya sastra, termasuk semenjak kedatangan Belanda ke Indonesia termasuk politik kolonialnya (Ronidin, 2010: 152). Beberapa karya sastra tersebut adalah Siti Nurbaya (1922) karya Marah Rusli, novel Salah Asuhan (1928), Pertemuan Jodoh (1932) karya Abdoel Moeis, dan Tjerita Boejoeng Bingoeng karya Aman Datoek Madjoindo, Azab dan Sengsara (1920) karya Merari Siregar, Hulubalang Raja (1932) Karya Nur Sutan Iskandar, Si Cebol Rindukan Bulan Karya Tulis Sutan Sakti, Katak Hendak Jadi Lembu karya Nur Sutan Iskandar (1935), Apa Dayaku Karena Aku Perempuan karya Jurnal IImu Sosial dan Humaniora |578 
Nur Sutan Iskandar (1922), Tak Putus Dirundung Malang karya Sutan Takdir Alisyahbana (1929).

Lahirnya karya sastra-karya sastra tersebut, yang sebagaimana dalam istilah Jauss (1983: 32) disebut dengan rangkaian sastra (literary series), menandakan jejak-jejak kolonial masih dapat dirasakan; dipertanyakan; ditinjau kembali, bahwa wacana kolonial itu menampilkan sebuah oposisi biner, yakni antara penguasa dan yang dikuasai; penjajah dan pribumi; hegemoni dan perlawanan; dan antara tuan/majikan dengan budak. Ashcroft, dkk (dalam Gandhi, 1998: iv) menyampaikan bahwa isu-isu mengenai dominasi dan subordinasi muncul pada awalnya ke permukaan berkenaan dengan kontrol militer kolonial. Budak digambarkan mengalami ketertindasan dari kaum majikan (bangsa penjajah); mereka disiksa dan dieksploitasi. Sebagai akibat dari eksploitasi itu, budak digambarkan melakukan perlawanan-perlawanan. Hasil penelitian Sudibyo (2007) pada novel Berpacu Nasib di Kebun Karet dan Kuli karya Madelon Szekely-Lulofs menyampaikan bahwa Novel Berpacu Nasib dan Kuli merepresentasikan kecenderungan praktik eksploitasi imperial Belanda pada awal abad ke-20 di perkebunanperkebunan karet di Deli. Kedua novel itu memposisikan kuli sebagai "sang liyan" yang pantas dipinggirkan dan dibinatangkan.

Penggambaran mengenai perlawanan pribumi digambarkan dalam karya sastra Siti Nurbaya karya Marah Rusli, Salah Asuhan, Pertemuan Jodoh karya Abdoel Moeis yang merupakan subjek pembahasan artikel ini.
Ada beberapa alasan pentingnya mimikri dan stereotipe kolonial terhadap kaum pribumi dalam novel-novel terbitan Balai Pustaka tersebut melalui kajian poskolonialisme dilakukan. Alasan berkenaan dengan posisi dan pentingnya karya sastra dan pengarang. Yang pertama adalah novel Siti Nurbaya. Novel ini dikatakan sebagai puncak-puncak kejayaan Balai Pustaka (Sarwadi, 2004: 33). Novel ini dikarang oleh Marah Rusli. Marah Rusli adalah pengarang penting dalam Balai Pustaka. Pentingnya Marah Rusli karena ia dapat mencipatakan karya sastra yang paling banyak dibaca oleh masyarakat (ibid).

Novel yang kedua adalah novel Salah Asuhan karangan Abdoel Moeis. Novel ini juga dapat dikatakan sebagai puncak-puncak kejayaan Balai Pustaka karena novel ini menyampaikan isi dan menggunakan bahasa yang sangat baik bagi Balai Pustaka. Akibat nilai sastra dan bahasa yang tinggi itulah, Abdoel Moeis juga tercatat sebagai pengarang penting bagi Balai Pustaka ketika itu (Sarwadi, 2004: 33). Yang ketiga adalah novel Pertemuan Jodoh karya Abdoel Moeis yang mengungkap kolonialisme didalamnya.

Pengungkapan kolonialisme dan adanya ideologi kolonialisme dalam novel Salah Asuhan juga menjadikan pertimbangan novel Pertemuan Jodoh sebagai novel yang dikarang oleh Abdoel Moeis sebagai subjek penelitian untuk mengungkap ideologi kolonialisme tersebut yang masih tersembunyi. Faruk (2009: 42) menyampaikan bahwa Abdoel Moeis terlibat dalam penulisan buku-buku Balai Pustaka dengan imbalan finansial yang tinggi.

Pada tahun 2010, Yasa pernah melakukan penelitian dengan teori Jurnal IImu Sosial dan Humaniora |579 
poskolonial, tetapi yang dikaji bukan pada mimikri dan stereotipe, melainkan orientalisme dan politik pencitraan Belanda terhadap pribumi. Selain itu, pada tahun 2011, Yasa juga pernah melakukan penelitian dengan menggunakan teori poskolonialisme pada novel-novel Balai Pustaka, tetapi objek kajian yang dilakukan bukan pada mimikri dan stereotipe, melainkan orientalisme dan politik pencitraan kolonial. Peneliti juga sudah sering melakukan penelitian sastra, tetapi bukan pada novel Balai Pustaka dengan menggunakan teori poskolonial.

Artikel ini mendeskripsikan (1) mimikri pribumi terhadap kolonial Belanda dalam novel-novel Balai Pustaka dan (2) stereotipe kolonial terhadap kolonial Belanda dalam Novel-novel Balai Pustaka.

Penelitian ini dapat memberikan beberapa manfaat. Manfaat yang dimaksud, antara lain (1) memperkaya khazanah kajian sastra Indonesia, terutama sastra Balai Pustaka dengan teori sastra mutakhir, (2) memperkaya topik atau wacana sastra tentang kajian poskolonial terhadap kesuasastraan di Indonesia yang akan dapat mempengaruhi pola pikir masyarakat tentang menganalisis sastra, dan (3) sebagai bahan pembelajaran dalam dunia pendidikan sastra Indonesia.

Makaryk

(1993:

menyatakan bahwa teori poskolonial merupakan sebuah istilah bagi sekumpulan strategi teoretis dan kritis yang digunakan untuk meneliti kebudayaan (kesusastraan, politik, sejarah, dan seterusnya) dari kolonikoloni negara-negara Eropa dan hubungan mereka dengan negaranegara lainnya di dunia. Meskipun tidak mempunyai aliran dan metode yang tunggal, teori poskolonial mempunyai banyak kesamaaan asumsi: mempertanyakan efek negatif dari apa yang justru dianggap bermanfaat bagi kekuasaan imperial, menyangkut isu-isu rasisme dan eksploitasi, dan mempersoalkan posisi subjek kolonial dan poskolonial.

Konsep dasar poskolonialisme dari masing-masing tokoh adalah paham yang meyakini bahwa efek-efek kolonial masih dirasakan oleh masyarakat bekas jajahan, walaupun mereka sudah merdeka. Selain itu, poskolonialisme juga meyakini bahwa pola-pola kekuasaan masa kolonial masih tampak dan diterapkan dalam kepemimpinan masa setelah kemerdekaan. Masa kepemimpinan Soeharto, sebagai mana ditulis McVery (dalam Faulcher, 2002: 1), sebagian besar penuh simbolik dan ciri organisasi Negara Hindia Timur pada puncak kekuasaan. Bahkan, Mangunwijaya menyampaikan bahwa "di Indonesia bulan Mei 1998, orang masih bisa melihat jejak 'Mataram, Hindia Timur Belanda, dan bala tentara Dai Nippon tetap masih hadir segar bugar dan kuat belum terkalahkan di negeri kami sampai sekarang" (Foulcher, 2002:2).

\section{METODE PENELITIAN}

Subjek penelitian ini adalah lima buah novel terbitan Balai Pustaka yaitu Siti Nurbaya karya Marah Rusli. Salah Asuhan karya Abdoel Moeis, Pertemuan Jodoh karya Abdoel Moeis, Katak Hendak Jadi Lembu, dan Hulu Balang Raja karya Nur Sutan Iskandar. Objek penelitian adfa;lah mimikri, mockery dan stereotife kolonial terhadapkaum budak.

Jurnal IImu Sosial dan Humaniora |580 
Pengumpulan data dilakukan dengan studi pustaka. Instrumen berupa kartu data. Data dianalisis dengan pendekatan postkolonialisme secara deskriptif dengan teknik dekontruksi : sebuah tindak pembacaan yang tidak sekadar merekontruksi makna teks yang asli tetapi juga melalui intrerpretasi melakukan dekontruksi tekstual secara interpretatif.

\section{HASIL DAN PEMBAHASAN \\ Mimikri dalam Novel-Novel Balai Pustaka}

Ashcroft menyampaikan bahwa perlawanan seperti itu dapat dikatakan bersifat radikal. Resistensi radikal merupakan perlawanan masyarakat terjajah terhadap kekuasaan kolonial. Resistensi radikal dicirikan oleh adanya rencana-rencana pergerakan yang terorganisasi, yang dilakukan dengan menyerang secara langsung melalui peperangan atau dengan memproduksi teks atau bacaan ( Lo and Gilbert, 1998: 12).

Selain bersifat radikal, Ashcroft (2001: 20) mengatakan bahwa resistensi itu juga bersifat pasif. Pada masyarakat poskolonial, resistensi sebagai perwujudan dirinya untuk menolak, yakni sebuah resistensi yang menggunakan cara lain dengan pemertahanan identitas dan kepemilikan budaya. Perlawanan/oposisi sering menjerat dalam wacana imperial untuk menaklukkan subjek jajahannya. Kontrol kolonial sangat kuat mengikat kaum terjajah. Pada dasarnya semua wacana kolonial selalu ada dalam oposisi biner, yakni penjajah/terjajah, beradab/biadab, putih/hitam dalam usaha melaksanakan cita-citanya untuk melakukan eskploitassi ekonomi secara politis (Ashcroft, 2001:21).

"Sesungguhnya kota Jakarta ini sangat besar dan sangat ramai; penuh dengan toko dan rumah yang besar-besar dan bagusbagus. Harus jadi ibu negara Indonesia", kata Nurbaya (Rusli, 189)

"Tentang peraturan Gubernemen ini, belum kami ketahui buruk baiknya. Tetapi yang mula-mula terasa dalam hati kami dalam perkara belasting ini, ialah orang Belanda rupanya telah kupa akan janjinya, kepada orang Minangkabau. Bukanlah sudah ditetapkan dalam "Pelekat Panjang" bahwa kami anak Minangkabau tak perlu membayar bia, yang sebagai belasting ini? Apakah sebabnya maka kami disuruh juga membayar, sekarang?" (Rusli, 249)

"Memang Belanda tak boleh dipercayai, bicaranya putar balik, sebagai lidah keling" (Rusli, 252).

Sementara itu, pada novel Pertemuan Jodoh, resistensi dilakukan oleh Ratna, seorang pembantu rumah tangga. Ratna dituduh mencuri di rumah majikannya, padahal ia sama sekali tidak pernah melakukannya. Karena dipandang sebagai pencuri kalung emas milik majikannya, ia dilaporkan ke polisi. Ratna tidak terima dengan perlakukan majikannya yang seorang Belanda itu. Akhirnya, ia melarikan diri dengan menceburkan dirinya ke sungai. Dalam konteks ini, Ratna sebagai

Jurnal IImu Sosial dan Humaniora|581 
pribumi melakukan perlawanan secara frontal.

Perlawanan yang dilakukan oleh Ratna akhirnya dapat membebaskan dirinya dari belenggu penjajah, majikannya. la akhirnya bertemua dengan tunangannya bernama Dokter Suparta dan ia menikah dengan lelaki itu.

\section{Stereotipe Kolonial dalam Novel- Novel Balai Pustaka}

Stereotipe kolonial dalam pandangan Edward Said, dibentuk oleh Barat atau kelas superior terhadap Timur. Timur merupakan negara bentukan yang mereka ciptakan atau sivilisasi agar menjadi beradab sebagai mana dirinya. Hubungan antara Timur dan Barat adalah hubungan kekuatan, dominasi, hubungan berbagai derajat hegemoni yang kompleks. Timur ditimurkan tidak hanya karena ia didapati dalam keadaan "bersifat Timur" dalam semua hal yang dipandang umum oleh rata-rata yakni mudah untuk -dijadikan Timur. Dalam konteks ini, stereotipe tidak terlepas dari paham oriental (orientalisme). Orientalisme bukanlah fantasi kosong orang Eropa mengenai dunia Timur, melainkan suatu sosok teori dan praktek yang sengaja diciptakan. Ada hegemoni gagasan-gagasan Eropa mengenai dunia Timur yang mengulangi pernyataan mengenai keunggulan Eropa atas keterbelakangan Timur. Realitas Timur adalah berbeda dengan realitas Barat; kebiasaannya, warna kulitnya yang eksotik, dan kenangan dan pengalaman yang indah. Timur harus dipahami memiliki keterbatasan dan kelemahan sehingga membutuhkan kekuatan dan pengetahuan Barat. Oleh karena itu, Timur siap untuk diatur kembali, diperintah, dikuasai, dan direkonstruksi.

Dalam novel Siti Nurbaya, kolonial mencitrakan tokoh Datuk Maringgih sebagai tokoh yang serba buruk.

"Badannya kurus tinggi, punggungnya bungkuk udang, dadanya cekung, serta kakinya pengkar, kepalanya besar, tetapi tipis di muka, serta sulah pula. Rambutnya yang tinggal sedikit sekeliling kepalanya itu, telah putih sebagai kapas dibusur. Misal dan janggutnya panjang, tetapi hanya beberapa helai saja. Giginya hitam dan kotor, yang di muka keluar sebagai gigi tupai. Telinganya besar, seperti telinga gajah, kulit mukanya berkarut-marut dan penuh dengan bekas cacar (Rusli, 84)

Dalam novel itu, kolonial Belnda juga menggambarkan Datuk Meringgih sebagai tokoh yang sangat kikir dan penuh dengan pehitungan.

"dicekiknya lehernya, diikatnya perutnya, ditahannya nafsunya, asal jangan keluar uangnya. Jika ia makan nasi, hanya dengan sambal lada atau ikan kering saja yang disimpannya sampai beberapa hari. Lauk pauk ini padalah baginya, karena sangkanya dapur yang berasap setiap hari, tiada berguna dan banyak mengeluarkan biaya. Rumahnya sebagai kandang kambing dan pakaiannya yang seperti pakaian kuli itu, tiada mengapa baginya, asal jangan keluar duitnya, untuk sekaliannya itu. (Rusli, 84).

Jurnal IImu Sosial dan Humaniora|582 
Kontruksi lain yang sengaja dibentuk oleh kolonial Belanda kepada para pribumi tampak pada upaya untuk mewajibkan para pribumi membayar belasting atau pajak hasil bumi. Para kolonial mengumpulkan para pribumi untuk mewujudkan upaya-upaya itu.

Sementara itu, orientalisme dalam novel Salah Asoehan lebih diperlihatkan oleh perilaku Corrie du bussie dan Hanafi. Berikut adalah bebeapa data tentang orientalisme yang ada pada Salah Asoehan karangan Abdoel Moeis.

"Aku tahu betul bahwa aku ini hanyalah Bumiputera sadja, Corrie! Djanganlah kau ulang-ulang djuga." (Moeis, 7).

"Timur tinggal Timur, Barat tinggal Barat, dan tidaklah keduanja akan mendjadi satu" (Moeis, 26).

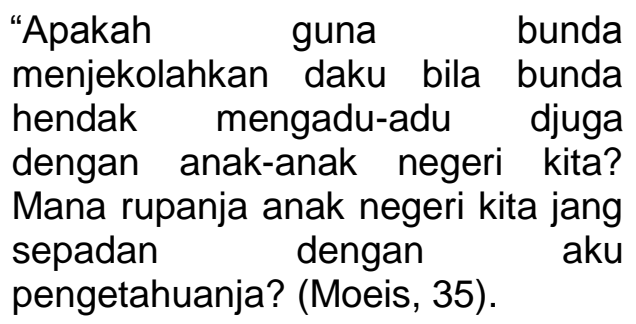

Pandangan inferior lain dari bangsa kolonial Belanda kepada masyarakat pribumi tampak pada novel Pertemuan Jodoh karangan Abdoel Moeis. Pandangan yang menggambarkan bahwa pribumi inferior tampak pada perilaku kolonial Belanda yang menuduh Ratna, pembantunya, sebagai pencuri perhiasan Nyonya Kornel. Dalam novel Pertemuan Jodoh, dikisahkan bahwa Ratna menjadi pembantu rumah tangga di rumah Nyonya Kornel. la dituduh mencuri perhiasan majikannya, padahal Ratna tidak mencurinya. Dalam konteks ini, pribumi yang direpresentasikan oleh Ratna dipandang kurang memiliki moral karena melakukan pencurian di rumah majikannya.

\section{PENUTUP}

Novel-novel Balai Pustaka memperlihatkan adanya mimikri. Mimikri sebagai satu bentuk resistensi yang dilakukan terhadap kolonial Belanda. Dalam Siti Nurbaya, perilaku Samsulbahri menjadi tentara Belanda adalah contohnya. Dalam Salah Asuhan, mimikri tampak pada perilaku Hanafi yang menirukan budaya barat. Dalam pertemuan jodoh, resistensi dilakukan oleh Ratna kepada majikannya yang tiada lain adalah kolonial Belanda.

\section{DAFTAR PUSTAKA}

Ashcroft, Bill, dkk. 1998. Key Concept in Postcolonial Studies. London and New York: Routledge.

Gilbert, Helen dan Jacqueline Lo. 1998.

Postcoloniality and The Question

of Modern Indonesian

Literature". An International

Reasearch workshop, The Rex Cramphorn Studio Centre for Performance Studies University of Sydney, Maret, 29-31.

Faruk. 2007. Belenggu Pasca-Kolonial.

Hegemoni dan Resistensi dalam

Sastra Indonesia. Yogyakarta :

Pustaka Pelajar.

Foulcher, Keith and Tony Day. 2002.

Postcolonial Readings of Modern

Jurnal IImu Sosial dan Humaniora |583 
Indonesian Literature Introductory Remarks. Eds. Keith Foulcher and Tony Day. Dalam Postcolonial Readings of Modern Indonesia Literature Clearing a Space. Leiden: KITLV Press.

Herawati, Yudianti. 2010. "Pemanfaatan Sastra Lokal dalam Pengajaran Sastra". Jurnal Lingua didaktika, Jurnal Bahasa dan Pembelajaran Bahasa, Volume3, Nomor2, Juli. ISSN 1979-0574.

Jauss, Hans Robert. 1983. Toward an Aesthetic of Reception. Minneapolis: University of Minnesota.

Makaryk, Irena R. 1993. Encyclopedia of Contemporary Literary Theory, Approaches, Scholar, Terms.
London: Toronto Buffalo, University of Toronto Press.

Mahayana, Maman S.1994. Politik Kolonial Belanda di Balik Pendirian Balai Pustaka. Universitas Indonesia. Laporan Penelitian. Tidak diterbitkan.

Sudibyo. 2007. "Menjinakkan Koeli : Praktik-praktik Dehumanisasi terrhadapKuli di Deli dalam Novel Berpacu Nasib di Kebun Karet dan Kuli karya Madelon SzekelyLulofs", $\quad$ www.geocities.com. Diunduh pada tangga 20 Oktober 2009.

Yasa, I Nyoman. 2011. Orientalisme, Pencitraan Budak dalam Karya Sastra Indonesia. Laporan Penelitian. 